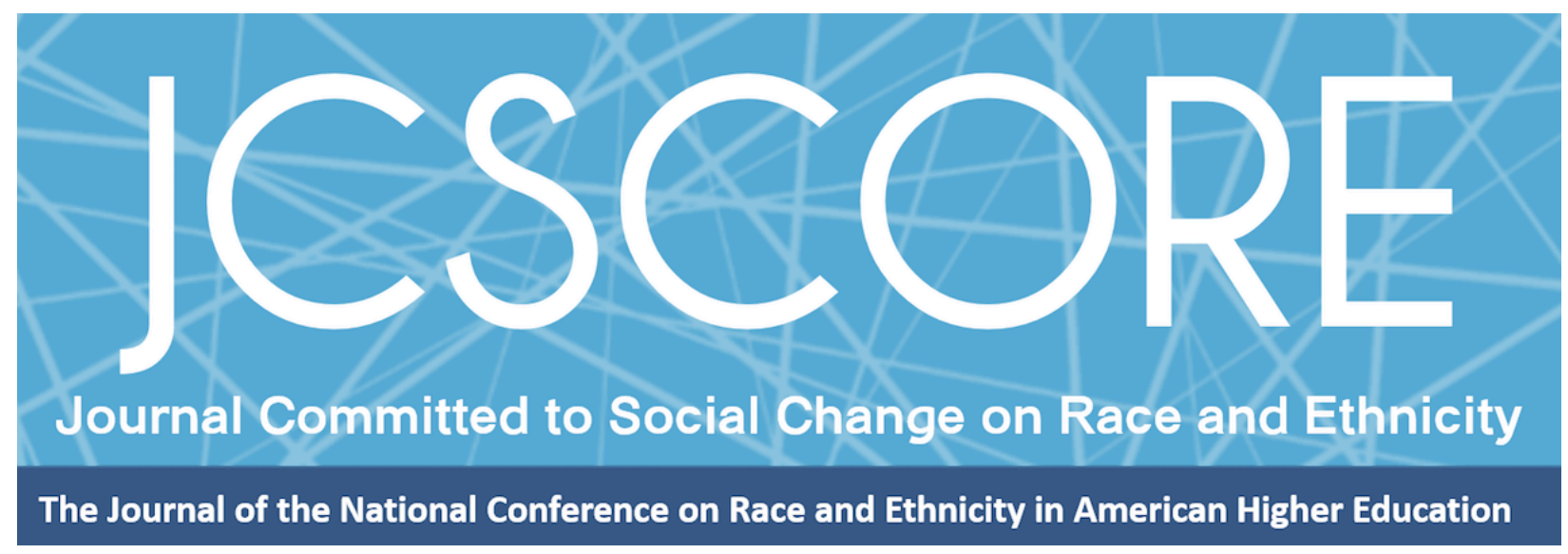

\title{
DISENGAGING WHITENESS AND EXAMINING POWER IN CAMPUS ACTIVISM: REUNITING COMMUNITIES OF COLOR THROUGH A CRITICAL RACE ANALYSIS OF TEMPERED RADICALISM
}

\author{
Veronica A. Jones \\ University of North Texas \\ Dian Squire \\ Northern Arizona University
}

Journal Committed to Social Change on Race and Ethnicity

Volume 4, Issue 1| 2018

Copyright (C) 2018 Board of Regents of The University of Oklahoma on behalf of the Southwest Center for Human Relations Studies.

Permission of the Publisher is required for resale or distribution and for all derivative works, including compilations and translations. Quoting small sections of text is allowed as long as there is appropriate attribution. 


\title{
Disengaging Whiteness and Examining Power in Campus Activism: Reuniting Communities of Color Through a Critical Race Analysis of Tempered Radicalism
}

\author{
Veronica A. Jones \\ University of North Texas \\ Dian Squire \\ Northern Arizona University
}

This manuscript provides a nuanced understanding of the heterogeneity of faculty and staff of color activism in the context of a racialized and racist university structure. Through the deployment of Critical Race Theory, and the couching of activism within a foundational white supremacist history of higher education, the authors are then able to repair discord between students who often see faculty and staff of color as complacent within their institutions. These critiques often do not take into consideration how racism constricts faculty and staff of color action and also comes with classist assumptions via an insinuation that all faculty and staff of color can risk loss of job as a result of activism. Moreover, an intersectional lens is not always considered in activism literature. At the same time, the authors argued that faculty and staff of color, particularly those who identify as Black, must be allowed to act in untempered ways as their livelihoods quite literally depend on changing a broader racist system.

The close of Freedom Summer stimulated a growing interest in human rights, and within the ivy walls of American colleges and universities the democratic pulse beat with a passion and verve never before witnessed. Armed with the tools of civil disobedience and a spirit radicalized by witnessing the American dream betrayed, thousands of college students committed themselves to transforming campuses into sites of social and political change. (Rhoads, 1998, p. 2)

Robert Rhoads (1998) wrote those words in his book Freedom's Web: Student Activism in an Age of Cultural Diversity about the summer of 1964. It was during that summer when thousands of college students registered African American voters in Mississippi amidst continued racial violence and death in their Southern state and across the country. More than fifty years later, the same words apply to students on 
Journal Committed to Social Change on Race and Ethnicity | 2018

college campuses across our nation. Today, students, staff, faculty, and community members, particularly Black individuals, are leading campus revolutions aimed at addressing racial injustice, histories of dominating Whiteness (Gusa, 2010; Hamer \& Lang, 2015; Patel, 2015), neoliberal reorganizing of institutional policies and practices (Giroux, 2002; 2015), and a diversity rhetoric that limits the power of social justice advocates to do critical transformative work (Berrey, 2015). These movements, as headlined by graduate student Jonathan Butler and the \#ConcernedStudent1950 supporters at the University of Missouri and the Next Yale group at Yale University, among others, highlight "both political and epistemological formation[s] that attempted to simultaneously disinter and reconstruct subjugated histories around race, gender, and nation" (Ferguson, 2012, p. 26). Indeed, gone are the days of promising more bodies of color to a campus in order to appease a "diversity agenda" that creates "missions of social justice upon an amnesia that forgets in order to sustain white settler colonialism" (Patel, 2015, p. 667). Because institutions increasingly transmit narratives of race neutrality and meritocracy to mask institutionalized supremacy, communities of color engage in a constant effort to critically examine these racist ideologies. Marginalized groups have taken upon a critical moment in time to change their campus contexts even as white racial solidarity and the protection of white liberal and conservative property rears its head (Ferguson, 2012).

This conceptual paper aims to analyze the ways that white supremacy limits the possibilities of engagement for communities of color (e.g., faculty, staff, and students) on college campuses. Namely, we analyze those communities of color who are finding it difficult to navigate their campus politics as it relates to forwarding racial justice and 
supporting racially minoritized others in creating change on college campuses. We find it problematic that students, faculty, and staff may be disjointed in their methods and determination at the expense of important coalition building for change. For example, Kezar, Bertram Gallant, and Lester (2011) found that faculty and staff often work behind the scenes to assist students in their activism efforts; those strategic actions are unknown to administrators and other actors across campus. Epistemological differences exist about the outward manifestation of resistance and change, based on traditional notion of activism as visible, disruptive, and collective. Therefore, individual actors must be aware of the ways in which a white supremacist structure aims to disconnect those who wish to deconstruct systems of oppression, void of an examination of how power ultimately constricts collective efforts.

We aim to reunite all people of color on campuses through three main discussions. First, we discuss campus activism in today's context and explore the roles that students and staff have in engaging in campus change. We take aim at the discourse around campus engagement and activism by disentangling the multifarious meanings of these words for white students and students of color; however, we understand that this critique can also be leveraged toward the ways faculty/staff of color are understood within these categories. We begin the process of negotiating the language between activism and engagement, answering the question: what is the difference between engagement and activism on college campuses for students of color, and Black students in particular?

Because of the ways that students of color are othered based on their engagement in campus activism, they may begin to feel unsupported by faculty and 
staff of color. However, we argue that one must begin to analyze how power commissions and disengages various campus communities from the battle for racial justice. To that end, we provide the framework of tempered radicalism (Meyerson \& Scully, 1995) as a structure for understanding how faculty and staff engage in campus activism. We also extend a critique of the framework through critical race theory. In this critique, we hope to illuminate the many ways that faculty and staff of color are constricted in their ability to navigate campus change politics and systems in order to inform other campus change agents about the realities of working within a dominating system of whiteness that holds power over people of color.

Lastly, we provide discussion on the many ways that the experiences of students of color and faculty and staff of color disjoin in order to better build foundational knowledge that allows each of these parties to build coalitions across institutional positionality. We believe that it is of the utmost importance that communities of color, students, faculty, and staff, do not allow the constraints of whiteness and power to separate them. Rather, we offer implications that encourage these groups to work in solidarity within the confines of their lived experiences and institutional realities to create positive social and systemic change on college campuses. We aim for this paper to spark both critical hope (Preskill \& Brookfield, 2009) and critical praxis (Freire, 1970/2000) on college campuses across the country as scholars and practitioners continue the fight toward racial justice.

\section{Students of Color: Engaged or Activists, or Engaged Activists?}

In this section, we define the ways in which students, faculty, and staff of color engage in campus change within the context of historical whiteness (Patel, 2015). To 
this end, we first provide foundational knowledge and critique of the ways that student engagement and activism are situated within the predominately white institution (PWI)

context, recognizing that within the discourse of engagement, universities often direct the lens of analysis of change toward the outside rather than toward the ivory tower. We highlight the ways that the terms "engagement" and "activism" hold different value related to the campus involvement of white students and students of color. We lastly link this campus rhetoric and reality to the ways that faculty and staff engage with students in creating campus change.

\section{Defining Student Engagement}

In order to achieve holistic strategies to support students of color in their campus engagement efforts, scholars and practitioners must recognize the language utilized in the theoretical principles of student development that often devalue and other the efforts of activists. Widely cited theorists champion student engagement as a vital goal of higher education, delineating involvement in the academic and social realms of campus life as an indispensable factor in the success of all college students (Astin, 1993; Chickering \& Gamson, 1987; Tinto, 1993). While the level of a student's engagement is intimately tied to outcomes such as persistence, retention, academic success, and social integration (Kuh, 2009), scholars have also problematized the basis of the seminal theories of student engagement (Patton-Davis, McEwen, Rendon, \& HowardHamilton, 2007). In deconstructing the boundaries in which theories were conceptualized, one notices that many of those seminal theorists based their research on samples of white, elite males, failing to consider the influence of various social differences such as race (Patton et al., 2007). Attempting to fill a gap in the literature, 
Journal Committed to Social Change on Race and Ethnicity | 2018

numerous studies have focused on the benefits students of color receive through campus engagement (Fischer, 2007; Strayhorn \& DeVita, 2010; Taylor \& HowardHamilton, 1995), often based on differing sets of needs and values than the dominant white group.

Discourse on student engagement must be viewed more critically as a theory of reciprocal engagement (Outcalt \& Skewes-Cox, 2002) and mutual influence between students and the institutional environment itself. Predominantly white institutions have been historically plagued with white ideologies that create messages of white privilege and depict people of color from a deficit perspective of inferiority (Duncan, 2017; Feagin, Vera, \& Imani, 1996; Gusa, 2010); factors that place students of color outside of a dominant norm undoubtedly affect not only the amount of time and energy they place into being significantly involved in campus life but also the outcome of their efforts. Student satisfaction with campus engagement opportunities and its correlation with positive outcomes must also factor in the negative impact of systemic racism within institutional spaces as related to the lived experiences of students of color (Dugan, 2017). For instance, students of color are more likely to consider not only individual interactions but also the structural factors of the institution in evaluating their campus experiences (Chavous, 2005). Scholars must examine the institutional messages of power and privilege that devalue the efforts of students of color. Although most institutions assert a commitment to providing civically responsible engagement opportunities for all students (Colby, Ehrlich, Beaumont, Stephens, 2003; Martin, 2014; O'Connor, 2006), the actual objectives and outcomes of engagement might serve a different capacity for students of color as part of a marginalized campus group. 
Because traditional ideals of engagement continuously place the onus on students of color to be engaged despite structural constraints, fighting institutional racism often becomes the foremost engagement activity for these students. Scholars must therefore disrupt the status quo by acknowledging alternate definitions of engagement that value a social justice lens and support them in challenging racial inequities.

\section{Emotional Labor}

In order to assess ways that faculty and staff can serve as advocates for students of color, one must negotiate the language of activism as situated within dominant normed engagement definitions that depict activism as a deleterious act against PWI principles. Activism is mainly posited as an effort and commitment to create change around economic, social, and political issues. These efforts are commonly connected with actionable techniques such as protest and demonstrations that allow individuals to utilize voice and to occupy physical spaces to contest various forms of injustice (Kezar, 2010; Ropers-Huilman, Carwile, \& Barnett, 2005). The contrast between the perception of engagement, as in line with the democratic ideals and mission of a university, and activism, viewed as disruptive and a nuisance to be managed (Martin, 2014), has implications for the resistance with which students of color are met when attempting to change their campuses. This resistance ties to the larger social message of those protecting capitalist values of privilege versus those who attempt to expose the power structures of institutions as having corrupted the academic environment (Leistyna, 2009).

Norms of PWls work to keep the historical and current disadvantages and exclusions of people of color unnamed and hidden; the transmitted message 
consequently relies on the assertion that the institution provides inclusiveness to all students and is thus a space of race neutrality (Evans \& Moore, 2015; Moore, 2008; Moore \& Bell, 2011). The onus once again is placed on the students who bear the weight of those oppressions to provide counternarratives regarding the microaggressions (Solorzano, Ceja, \& Yosso, 2000) and institutionalized racist practices they experience as a lived reality. Critical race theory (CRT) is named as a theoretical frame utilized to challenge a dominant master narrative of race neutrality and objectivity, through the assertion of standards of whiteness as the foundational principle of United States institutions (Ladson-Billings and Tate, 1995; Morfin, Perez, Parker, Lynn, \& Arrona, 2006). Counternarratives as a major tool of CRT serve as a means to give voice to marginalized students by naming an alternate reality that highlights their experiential knowledge with the truths of racism (Delgado Bernal, 2002; Duncan, 2017; Yosso, 2005). Some students of color may choose to channel their counternarrative through activism, seeking to eliminate the racist practices of the very institutions that claim race neutrality.

While activism can be transformative for students of color by empowering them to have some sense of agency in such settings of veiled power and privilege, they are functioning within a white frame that works to other people of color as culturally inferior. Evans and Moore (2015) elaborate on how resistance to racism is problematized by the framing of people of color as unobjective or deviant:

The ideological and discursive construction of people of color as overly emotional, overly focused on race, too sensitive, etc., means that people of color within the institution are constructed in such a way that their resistance to racist organizational structures or denigrating racist incidents is countered before it occurs. (p. 445) 
The fear of being characterized as emotional goes beyond labeling; for people of color, active resistance against racism can result in material consequences such as further alienation, sanctioning, and even official reprimands such as expulsion (Evans \& Moore, 2015; Pierce, 2012). Students of color bear the weight of not only resisting racist institutional practices but also providing themselves with emotional protection from the very racism they resist in order to avoid those consequences (Moore, 2008). Within that emotional management, marginalized students understand that while their white counterparts do not have to engage in that emotional work, they must invoke various strategies that allow them to function in what is so often a volatile environment.

The notion of emotional labor is further complicated by the intricate processes of decision-making for students of color in deciding when to challenge racial oppression and when not to. This process includes the understanding that choosing not to engage in active resistance will reproduce racist power structures. One must question, do activists who feel obligated to act against social inequity and most often take the lead role in calling their student community to action feel that disengagement to avoid emotional trauma is an option? Activists may bear an additional layer of emotional management in choosing the consequences of resistance over their own emotional sanctity, further necessitating increased support from institutional members.

The ideal of aggression is not within the act of active resistance itself. Instead "aggression" lies within institutional actors who are antagonistic in discouraging the disruption of the "tranquil" existence of racial oppression. There needs to be acknowledgement of this intimidation as a realized threat when discussing the engagement efforts of students of color. Activists are often placed on the periphery to 
what is considered desirable engagement because they bring attention to the existence of the racist truths PWIs intend to be hidden. We contend that dominant normed messages of engagement exclude students of color, perpetuate resistance against student activism, and therefore necessitate new definitions that aid in student empowerment. Engagement that resists campus contradictions of oppression and power stands as a high-risk activity that perhaps requires increased support in comparison to standard undertakings of campus involvement, support faculty and staff can provide.

\section{The Role of Faculty and Staff in Activism}

Frameworks that advocate for student activism must challenge campus leaders to problematize their own oppressive practices and also encourage faculty and staff to provide the support students need to be heard and make an impact on campus. The student-faculty as well as student-staff relationships are particularly essential for students of color in that people of color who work within the structural constraints of the PWI environment can assist students in navigating those constraints. Faculty and staff can be essential in socializing students of color, particularly activists, into the basic survival strategies needed to combat the everyday microaggressions of the neoliberal university. In equipping students with knowledge of their own lived experiences with institutional oppression, this partnership can be essential in helping students of color to view faculty and staff of color as advocates.

While faculty and staff can act as mediators between students and administrators (i.e. those of elite status who hold actual decision-making power), this relationship needs to be further contextualized in the battles of people of color to be seen as 
legitimate to those very administrators in the academy (Patel, 2015). While this system of support is favorable for campus activism, one must first consider the limitations in which faculty and staff of color are placed that might prevent them from such support. Faculty of color deal with paralleled microaggressions of racial prejudice in their everyday institutional experiences. These include questioning their legitimacy and competence in their field, their rightful place in the institution as so-called diversity hires, and the backlash they receive in presenting the truths of structural racism in their courses (Hamer \& Lang, 2015; Patel, 2015). Just as we problematize the comparison of the engagement of students of color to a dominant norm, one must also more critically assess how these racist manifestations affect the ability of faculty and staff of color to support activist efforts. In developing student activism as a learning outcome, faculty and staff can empower students to understand the language of those in power and how to negotiate within the system (Kezar, 2010).

A better understanding of the counternarratives of racism as a permanent fixture in the experiences of faculty and staff of color can allow students to make parallel connections to their own experiences. The heterogeneity of strategies that faculty and staff of color utilize to navigate the systemic barriers of a racialized bureaucracy can serve as opportunities through which students of color can gain insight into the various tools accessible to stand up against institutional racism. In the following section, we attempt to highlight the various challenges that faculty and staff of color face as people of color within the dominant whiteness of the PWI. The idea of the tempered radical has been forwarded as an apt framework from which people within organizations who have differing values from the organization but who also believe in the mission of the 
organization can create positive change. However, we find issue with tempered radicalism at face value and extend a critique of the framework in order to better illustrate the possible contradictions in values and actions as framed within a racialized society. It is our hope that this illustration provides students wishing to be in solidarity with faculty and staff a better understanding of the constraints of those people within the university context in order to provide more authentic and meaningful coalition building toward campus racial equity.

\section{Faculty and Staff of Color as Change Agents in the PWI}

This section briefly reviews the concept of the tempered radical forwarded by Meyerson and Scully (1995) in their seminal piece Tempered Radicalism and the Politics of Ambivalence and Change. Through an additional lens of critical race theory (CRT) (Delgado \& Stefancic, 2001), we further articulate how people of color (defined as anybody who does not identify entirely as white) exist as tempered radicals within the university setting, particularly as they align with racial justice movements on college campuses. This perspective stems from the understanding that one's experience is influenced by social constructions of race and their material consequences (Omi \& Winant, 1994) and other systems of oppression such as genderism, classism, and ableism. Through this analysis we examine systems of power, notions of collegiality and civility, cycles of engagement contemplation, and additional tensions to engagement as a tempered radical.

Meyerson and Scully (1995) aptly recognize that people of color and lesbian, gay, bisexual, and trans people experience the university differently from others; however, they fall short in truly describing how people of color exist within their 
framework. Indeed, 37 of the 48 people interviewed for Meyerson's (2001) follow-up book project were white men or women; four of the 48 were Black, an important consideration when understanding racial and social justice (broadly informed by the \#BlackLivesMatter movement). We argue that Meyerson and Scully fail to truly implicate historic systems of oppression in their understanding of change within the organizational setting and how those organizations shape the racialized experiences of faculty and staff of color. As a result, there is a false sense of agency placed upon all people who wish to engage with organizational change that fails to acknowledge the historical whiteness of college campuses.

\section{Tempered Radicalism}

The idea of the tempered radical emerged when two white feminist businesswomen, Debra Meyerson and Maureen Scully, observed that there were leaders within organizations who "must struggle continuously to handle the tension between personal and professional identities at odds with one another" (Meyerson \& Scully, 1995, p. 586). Essentially, they argued that, in order to navigate cultural, political, and personal relationships within organizations, one must be tempered in their actions to change an organization. The modifier tempered describes an individual who is moderate in action, may be angered by incongruence values, and an individual who may act in some moments and not others. Integral to the tempered radical identity, a person enters a space with both personal and professional values deeply engrained in their being; they believe in both the self and the missions and values of an organization.

In their model, Meyerson and Scully (1995) suggested, "individuals can remain ambivalent and quite clear about their attachments and identities" (emphasis original, p. 
588). Therefore, tempered radicals can be "outsiders within" (Meyerson \& Scully, 1995, p. 589), can critique the status quo, critique those who wish to move in "untempered" or more radical ways, and can advocate for both ways of moving through a system. Rightly, the authors identify ways in which more conservative or progressive actors may lambast tempered radicals due to this identity choice, a form of critique also often leveraged by students against faculty and staff of color whom students perceive as failing to act in racial solidarity.

Identifying the challenges of being a tempered radical, Meyerson and Scully (1995) illustrated the ways that tempered radicals may ultimately leverage accumulated capital to make change in incremental ways. These changes may be based on the positions of power that they accrue over time within an organization and may be "small wins" (p. 595) or "local spontaneous, authentic action" (p. 596). This ideal can be likened to Avolio and Gardner's (2005) description of authentic leadership as action taken by leaders who are true to themselves, are motivated by values and understanding of self, create their own personal ideas, and act altruistically. Tempered radicals most often make changes by quietly engaging in personal actions, confronting discrimination, negotiating alternatives to conflict, using small "wins" in organizational change to influence larger change, and organizing collective action (Kezar et al., 2011). We move to the framework of critical race theory to extend the tempered radical concept as relevant to current movements of social justice within the structural constraints of higher education.

The Audacity of Temper 
Before extending an understanding of tempered radicalism through a lens of critical race theory, we must be clear that there is some level of fault with utilizing the framing for people of color within white supremacist structures. This is due to the fact that we understand tempering as a privileged notion that must be identified as such. Universities were quite literally built upon the bodies and economies of Black and Native/Indigenous peoples of the land now known as North America (Wilder, 2013). There is a right to be radical. There is a call to act. The idea that one might temper themselves in order to continue to exist within a white supremacist structure and not address the emotional or physical violence enacted upon them on a daily basis is an act of self- and imposed- dehumanization. The audacity of temper determines that one ignores the self as human. Within an educational context, tempering is an act that must not be continually enabled by structures of domination, namely racism, and those who uphold those structures. White supremacy must be fought against and allowed to be radically deconstructed without repercussions.

"Tempered" as a modifier to "radical" allows those who have the time, energy, and space to engage in slow change to do so in a safe and moderated environment. It allows one to reap the benefits of incremental change and the praise for working within a system that already benefits them most. Black and Brown people at the intersections of their queer and trans identities, sexual identities, disabilities, class statuses, among others, must double down on their efforts to radically change the systems they love and work in; a lack of change might quite literally be life or death. The audacity of temper has the potential to silence and isolate people of color. It has the opportunity for renegotiating a new organization made from pieces the crumbling planks of older 
Journal Committed to Social Change on Race and Ethnicity | 2018

structures. A tempered radicalism is a violent action toward people of color and a radicalism that upholds White supremacy.

People of color do not simply engage with universities differently than white people; they have been historically positioned to fail, continually resisting and thriving and succeeding against structures that aim to keep them lesser than. A new tempered radicalism brings light to the systemic oppressions that frame the experiences of people of color and provides new lenses from which to understand their varied experiences. The framing of tempered radicalism as privileged and an extension of the framework through a critical race lens provides nuance to the experiences of faculty and staff of color. The audacity of tempering may be silencing; but the critical race tempered radicalism may be liberatory.

\section{Critical Race Deconstruction and Reconstruction of Tempered Radicalism}

Critical race theory (CRT) is an apt theory through which to critique tempered radicalism because it centers the experiences of people of color and understands race and racism to be endemic to life in the United States (Delgado \& Stefancic, 2001). CRT also posits that race and racism shape the everyday human experience (Dixon \& Rousseau, 2005). Aside from understanding racism as normal and ordinary in everyday life, CRT challenges dominant liberal, meritocratic, color-blind, and neutral ideology (Delgado \& Stefancic, 2001). CRT values an interdisciplinary lens and understands the human experience at the intersections of one's identities. Crenshaw (1991) noted that intersectional analyses highlight the intragroup differences in experience and how one's multiple identities interact to influence one's life. These interactions are influenced by understandings of power, privilege, and oppression in different social locations (Hulko, 
Journal Committed to Social Change on Race and Ethnicity | 2018

2009). Social locations are the various spaces where one exists that may privilege or marginalize one's identities. Understanding social location allows a deep analysis of structural intersectionality (Crenshaw, 1991).

Lastly, CRT requires action be taken in order to deconstruct systemic racism and to re-form a more just world (Dixson \& Rousseau, 2005). A deconstructed tempered radicalism takes into account the pervasiveness of racism and understands faculty and staff at the intersections of their identities within a white supremacist context.

Therefore, we contend that an understanding of identity within a social location must be taken into account in understanding how one enacts change on campus. Secondly, we deconstruct one's ability to be entirely authentic in creating change and how that relates to taking action. Third, we provide additional considerations for understanding faculty and staff of color in relation to campus change.

Intersectional Social Location. A deconstruction of tempered radicalism begins with understanding how faculty and administrators of color exist at the intersections of their identities and how power plays into the ways that they make decisions on college campuses. Devoid of consideration of how race, sex, gender, class, ability, sexual orientation, and other identities intersect, power may reinforce systems of oppression and create hegemonic normativity (Foucalt, 1977). Despite recognition that race may influence one's ability to create change, there is no critical analysis of those influences in the original tempered radical framework. Polyvalent power exerts forces on people at various times from all directions (Metro-Roland, 2011). Depending on one's social location, identity salience, and privilege, one may not be able to challenge institutional norms without risk of harm (Squire, 2016). In changing 
organizations, Holvino (2010) notes that people of color will employ logics in various ways depending on an assessment of environmental factors, including safety. Essentially, in each social location, people of color must engage in a cycle of contemplation. Technologies of domination (Foucault, 1977) such as faculty tenure and promotion, hierarchical reporting structures, surveillance, police, social media, or student assessments may restrict movement. This is in light of current research that shows that people of color are already negatively viewed in some areas of campus life (e.g., classroom evaluations and tenure/promotion; Ahmed, 2012; Delgado-Bernal \& Villalpando, 2002; Patitu \& Hinton, 2003; Turner, 2002) making the risk of taking action much higher.

Authenticity and Action. In a tempered radical framework, one may make subtle actions that are seen as authentic and aligned with one's values. Based on this authenticity, organizations may experience change as people trust the change-agent to do what is best for the organization based on what they know about that person. However, we challenge a benevolent understanding of authenticity. We ask: What is authenticity and who is allowed to be authentic? Through a CRT analysis, race and racism are forwarded and understood as endemic to everyday life and therefore embedded within an analysis of authenticity. Again, people engage in contemplative action related to emotion, value, instrumental needs, or habit (Weber, 2009). Weber (2009) argues that values-oriented deliberations become concrete actions as values are solidified within oneself. This begs the question: how is an individual who is deeply embedded within and affected by systems of racism on a daily basis able to act in a tempered manner, when the value of racial justice is so central to their personal value 
system? If a person of color's authenticity reveals itself as anger toward a situation, sadness, or fear, there is a true risk for being seen as a threat, weak, incapable of making decisions, or subjective. Authenticity is reserved only for the privileged and those who engage in a project of maintaining Whiteness (Lipsitz, 2006).

Civility and Collegiality. The ability to be authentic is directly linked to one being seen as civil or collegial. Within the literature on faculty of color, the effects of being viewed as civil and collegial have potential impacts on the tenure and promotion process, the core mechanism for retaining employment as a faculty member (Haag, 2005). Stockdill and Danico (2012) stated that "when [people] from oppressed groups speak out against systemic institutional and cultural factors....many faculty and administrators view them at best as non-collegial and at worst as the sources of conflict" (p. 17). The rhetoric of civility and collegiality is a technology of domination that silences people of color before they can express an opinion. If one's well-being is predicated on employment, then keeping that employment secure is of the utmost importance. This tension highlights a classist assumption embedded within the tempered radicalism model that must be revealed. As Squire (2016) noted: "just as post-racialism hides a racist's actions from clear sight, oppression and marginalization are hidden behind civility and collegiality" (p. 117). Tempered radicals have the ability to slowly change their organizations and retain economic stability and relative emotional and psychosocial health. However, a deconstruction of tempered radicalism creates opportunities to fully understand how faculty of color engage in change.

Student perceptions. The final consideration we present in this paper regards student perceptions of faculty and staff. Students may have particular perceptions of 
Journal Committed to Social Change on Race and Ethnicity | 2018

faculty and staff of color leading them to expect certain behaviors to occur. If those behaviors do not occur, there may be continued or heightened discontent. It is in these moments that students realize they do not have navigational capital to understand how universities are organized and how change happens within higher education institutions (Yosso, 2005). Faculty and staff should work with students to not only provide opportunities for students to engage with their activist identities, but they must also engage in conversations about how change occurs on college campuses. Therefore, building a stronger relationship with students in order to explore each person's knowledge, abilities, opportunities, and even positional location within the institution is of the utmost importance to understanding how one may engage in the heterogeneity of activism.

Reconstructing tempered radicalism takes into finer account the multiple complexities of identity as they relate to a person of color's social location within a university setting that was built on white settler colonialism (Patel, 2015). It is not simply enough to reflect that people of color have different experiences with creating change (Meyerson \& Scully, 1995). In order to forward the framework of tempered radicalism, one must examine the ways that power exerts on people of color to constrict their abilities to fully show up in a space as one's self and therefore make radical change. Through this analysis, we are then able to better understand the heterogeneity of activism for faculty and staff. Rather than understanding activism as large, overt acts of dissent, faculty and staff may engage in smaller actions such as pushing back on oppressive structures in leadership meetings, reforming admissions criteria, mentoring minoritized students, and academic publishing, among other activities. 
Journal Committed to Social Change on Race and Ethnicity | 2018

\section{Discussion and Implications}

The facilitation of student movements by faculty and staff who hold higher positions of authority in the institutional hierarchy can aid in activist efforts. Astin (1975) attested that faculty could serve as a bridge between students and administrators in making activism efforts more effective; when faculty were involved there was less involvement of the police and student protests were seen as more legitimate (Kezar, 2010). However, the complexity of a racialized bureaucratic system must be considered in understanding how students' perceptions of support from faculty and staff can be convoluted. For example, it is often unclear which staff members, such as advisors or other student affairs personnel, hold administrative power, either being viewed as an asset or hindrance as a player of the system students oppose (Ropers-Huilman, Carwile, \& Barnett, 2005). Through our discussion of the theoretical underpinnings of resistance, we offer several implications that acknowledge the positionality of students, faculty, and staff and will lead to increased solidarity. Related to the role of advocacy, we recommend the following strategies in the areas of: 1) recognizing the heterogeneity of resistance; 2) being transparent about the emotional labor involved in resistance; and, 3) placing race and power at the forefront of scholarship and advocacy.

First, just as mentoring and navigational capital are tools utilized to increase the social and academic outcomes for students of color (Reddick, 2012; Yosso, 2005), student affairs professionals can empower students with knowledge of the heterogeneity of resistance. A more comprehensive understanding of these strategies can assist students in battling the constraints of institutionalized racism. Students most often stage resistance in visible and overt ways, most commonly known through 
material or physical acts such as protests and marches, and expect faculty and staff of color to engage in the same ways. Hollander and Einwohner (2004) emphasized "everyday resistance" as acts that are imperceptible to those in power but allow individuals to oppose structural constraints. They attest that these undetectable techniques "can go unnoticed by the powerful, which helps protect the powerless from repression by masking the resistant nature of their activities" (Hollander \& Einwohner, 2004 , p. 539). In order to go unnoticed by those in power, critical race tempered radicals frame resistance to be more aligned with academic culture. These unobtrusive resistance tactics include organizing intellectual opportunities (e.g. sisterhood networks), consciousness-raising through professional development, participating on hiring committees, and utilizing data to create awareness of inequity (Kezar et al., 2011). While faculty and staff of color continue to refine these strategies as fundamental to successfully challenging inequity, outsiders (i.e. the student activist) might lack the cultural knowledge to be able to identify the intent behind such resistance (Hollander \& Einwohner, 2004). It is therefore essential that through formal and informal practices we allow students to make meaning of the subsequent tactics of resistance that reflect the complexities of forging partnerships for activism.

Additionally, faculty and staff can be more transparent about the emotional labor they experience in deciding on the tactics of resistance, which can build a better understanding for students who may perceive that they lack support. Students of color who are actively involved in disrupting campus inequity face reprimand and further marginalization, just as faculty and staff of color avoid the negative consequences of speaking out against racialized practices in the academy. Students may see faculty and 
Journal Committed to Social Change on Race and Ethnicity | 2018

staff of color as holding greater power to implement activism efforts; however, it is possible for individuals to be both powerful and powerless within the same system (Curtin, Kende, \& Kende, 2016). Therefore, staff and faculty of color should be intentional in including their own narratives of the emotional management associated with how their behaviors will be co-opted within a white supremacist framework. Being an actor within an oppressive structure includes the emotional burden of protecting oneself and in some ways reproducing those racialized relations of power (Evans \& Moore, 2015). When students understand the various mechanisms of oppression that faculty and staff experience, there may be stronger, more trust-driven relationships that form. This education does not require that students completely change tactics or that they be tempered in their own activism; rather, there is a more nuanced understanding of the student role and the faculty/staff role within this context. There is also a need for each constituency to try to understand the lived experiences of the other. Students have different constraints, as do staff and faculty. By bringing this vulnerability to discourse with students, faculty and staff can ultimately galvanize individual acts as more of a collective effort.

Finally, we suggest that practitioners place race and the effects of power at the forefront of scholarship and advocacy for marginalized communities. For example, while Kezar (2010) explored the tactics staff and faculty utilize in assisting students in unobtrusive ways, race and the variance of experiences for participants of color were not explicitly explored as a hindrance to the support of activism. It essential to maintain a critical lens on the power and systemic racism that often remains hidden or treated as a secondary factor in analyzing partnerships with student activists. Harrison (2010) 
Journal Committed to Social Change on Race and Ethnicity | 2018

found that the training and development provided to professionals often fails to include the potential consequences of challenging power structures when advocating for students. Further, her findings revealed that staff who did choose to overtly challenge oppressive practices lost their jobs or promotional opportunities. Being more upfront about these racial realities for advocates of students will aide in naming the very power structures that continue to remain hidden and reproduced.

\section{Conclusion}

Resistance is not a dichotomous act; tempered radicals often take action on a continuum of resistance depending on the risks associated with their actions. This bind provides ripe space for internal discontent among campus change agents and possible breaking down of necessary coalition building across institutional actor groups (i.e., students, staff, and faculty). Therefore, it becomes abundantly important to reveal the ways that student, faculty and staff experiences parallel across the institution. While students, faculty, and staff of color all constitute different positions within the institutional hierarchy, they are nonetheless all actors in a social system of which they all experience various forms of oppression. In understanding how each of these groups rationalize their own positionality within an oppressive structure, we can perhaps bridge the perceptional gap of each group by connecting the language utilized within each of those locations. The complexity of faculty and staff as tempered radicals requires that they grapple with the contradictions of supporting the very structures (e.g., tenure and promotion) that impose various forms of discrimination upon them as professionals. While the coping strategies to counter such stressors are considered to be unique 
based on racial and gendered-race based locations, it is also important to relate professional and identity factors to those processes.

Ultimately, individuals who choose to use more tempered strategies and even observers can struggle with determining if such actions are indeed impactful and effective in challenging institutional racial hierarchies (Hollander \& Einwohner, 2004; Kezar et al., 2011). By providing more spaces for groups to share their counternarratives of the emotional management involved in their roles, we can connect their perspectives through the commonalities of power relations. It is only through these revelations and continued discussion that students, faculty, and staff can act in solidarity with each other toward deconstructing white supremacist institutions and creating more just and equitable organizations for the success of students, faculty, and staff of color. 


\section{References}

Ahmed, S. (2012). On being included: Racism and diversity in institutional life. Durham, NC: Duke University Press.

Astin, A. W. (1975). Preventing students from dropping out. San Francisco, CA: JosseyBass.

Astin, A. W. (1993). What matters in college? Four critical years revisited. San Francisco, CA: Jossey-Bass.

Avolio, B. J., \& Gardner, W. L. (2005). Authentic leadership development: Getting to the root of positive forms of leadership. The leadership quarterly, 16(3), 315-338.

Berrey, E. (2015). The enigma of diversity: The language of race and the limits of racial justice. Chicago, IL: University of Chicago Press.

Chavous, T. (2005). An intergroup contact-theory framework for evaluating racial climate on predominantly white college campuses. American Journal of Community Psychology, 36, 239-257.

Chickering, A., \& Gamson, Z. (1987). Seven principles of good practice in undergraduate education. AAHE Bulletin, 7(3), 3-7.

Colby, A., Ehrlich, T., Beaumont, E., Stephens, J. (2003). Educating citizens: Preparing America's undergraduates for lives of moral and civic responsibility. San Francisco, CA: Jossey-Bass.

Crenshaw, K. (1991). Intersectionality and identity politics: Learning from violence against women of color. Stanford Law Review, 42(6), 1241-1299.

Curtin, N., Kende, A., \& Kende, J. (2016). Navigating multiple identities: The simultaneous influence of advantaged and disadvantaged identities on politicization and activism. Journal of Social Issues, 72(2), 264-285.

Delgado Bernal, D. (2002). Critical race theory, Latino critical theory, and critical racedgendered epistemologies: Recognizing students of color as holders and creators of knowledge. Qualitative inquiry, 8(1), 105-126.

Delgado Bernal, D., \& Villalpando, O. (2002). An apartheid of knowledge in academia: The struggle over the" legitimate" knowledge of faculty of color. Equity \& Excellence in Education, 35(2), 169-180.

Delgado, R., \& Stefancic, J. (2001). Critical race theory: An introduction. New York, NY: NYU Press.

Dixson, A. D., \& Rousseau, C. K. (2005). And we still are not saved: Critical race theory in education ten years later. Race Ethnicity and Education, 8(1), 7-27.

Dugan, J. P. (2017). Leadership theory: Cultivating critical perspectives. San Francisco, CA: Jossey-Bass.

Duncan, G. A. (2017). Critical race ethnography in education: Narrative, inequality, and the problem of epistemology. In A. Dixon, \& C. K. Rousseau (Eds.) Critical race theory in education: All God's children got a song ( ${ }^{\text {nd }} \mathrm{Ed}$.) (pp. 191-212). New York, NY: Routledge.

Evans, L., \& Moore, W. L. (2015). Impossible burdens: White institutions, emotional labor, and micro-resistance. Social Problems, 62(3), 439-454.

Feagin, J. R., Vera, H., \& Imani, N. (1996). The agony of education: Black students at White colleges and universities. New York, NY: Routledge.

Ferguson, R. A. (2012). The reorder of things. Minneapolis, MN: University of Minnesota Press. 
Foucault, M. (1977). Discipline and punish: The birth of the prison. New York, NY: Vintage.

Fischer, M. J. (2007). Settling into campus life: Difference in race/ethnicity in college involvement and outcomes. Journal of Higher Education, 78, 125-161.

Freire, P. (2000). Pedagogy of the oppressed. London, UK: Bloomsbury Publishing.

Giroux, H. (2002). Neoliberalism, corporate culture, and the promise of higher education: The university as a democratic public sphere. Harvard educational review, 72(4), 425-464.

Giroux, H. A. (2015). Democracy in crisis, the specter of authoritarianism, and the future of higher education. Journal of Critical Scholarship on Higher Education and Student Affairs, 1(1), 7.

Gusa, D. L. (2010). White institutional presence: The impact of Whiteness on campus climate. Harvard Educational Review, 80(4), 464-490.

Haag, P. (2005). Is collegiality code for hating ethnic, racial, and female faculty at tenure time? The Hispanic Outlook in Higher Education, 2005, 57-62.

Hamer, J. F., \& Lang, C. (2015). Race, structural violence, and the neoliberal university: The challenges of inhabitation. Critical Sociology, 41(6) 897-912.

Hollander, J. A., \& Einwohner, R. L. (2004). Conceptualizing resistance. Sociological Forum, 19(4), 533-554.

Holvino, E. (2010). Intersections: The simultaneity of race, gender and class in organization studies. Gender, Work \& Organization, 17(3), 248-277.

Hulko, W. (2009). The time-and context-contingent nature of intersectionality and interlocking oppressions. Affilia, 24(1), 44-55.

Kezar, A. (2010). Faculty and staff partnering with student activists: Unexplored terrains of interaction and development. Journal of College Student Development, 51(5), 451-480.

Kezar, A., Bertram Gallant, T., \& Lester, J. (2011). Everyday people making a difference on college campuses: The tempered grassroots leadership tactics of faculty and staff. Studies in Higher Education, 36(2), 129-151.

Kuh, G. D. (2009). What student affairs professionals need to know about student engagement. Journal of College Student Development, 50(6), 683-706.

Ladson-Billings, G., \& Tate, W. F. (1995). Toward a critical race theory of education. Teachers college record, 97(1), 47.

Leistyna, P. (2009). Preparing for public life: education, critical theory, and social justice. In W. Ayers, T. Quinn, \& D. Stovall (Eds.), Handbook of social justice in education (pp. 51-58). New York: Routledge.

Lipsitz, G. (2006). The possessive investment in whiteness: How white people profit from identity politics (2nd ed.). Philadelphia, PA: Temple University Press.

Martin, G. L. (2014). Understanding and improving campus climates for activists. New Directions for Higher Education, 2014(167), 87-92.

Meyerson, D. (2001). Tempered radicals: Everyday leadership transforming organizations. Cambridge, MA: Harvard University Press.

Meyerson, D. E., \& Scully, M. A. (1995). Crossroads tempered radicalism and the politics of ambivalence and change. Organization Science, 6(5), 585-600.

Metro-Roland, D. (2011). Knowledge, power, and care of the self: The many faces of Michel Foucault in education research. In B. A. Levinson, J. P. Gross, C. Hanks, 
J.H. Dadds, K. Kumasi, \& J. Link (Eds.). Beyond critique: Exploring critical social theories and education (pp. 139-170). New York, NY: Routledge.

Moore, W. L. (2008). Reproducing racism: White space, elite law schools, and racial inequality. Lanham: Rowman \& Littlefield Publishers.

Moore, W. L., \& Bell, J. M. (2011). Maneuvers of whiteness: 'Diversity' as a mechanism of retrenchment in the affirmative action discourse. Critical Sociology, 37, 597-613.

Morfin, O. J., Perez, V. H., Parker, L., Lynn, M., \& Arrona, J. (2006). Hiding the politically obvious: A critical race theory preview of diversity as racial neutrality in higher education. Educational Policy, 20, 249-267.

O'Connor, J. S. (2006). Civic engagement in higher education. Change: The Magazine of Higher Learning, 38(5), 52-58.

Omi, M., \& Winant, H. (1994). Racial formation in the United States. From the 1960s to the 1990s. 2nd Ed. New York, NY: Routledge.

Outcalt, C., \& Skewes-Cox, T. (2002). Involvement, interaction, and satisfaction: The human environment at HBCUs. The Review of Higher Education, 25, 331-347.

Patel, L. (2015). Desiring diversity and backlash: White property rights in higher education. The Urban Review, 47(4), 657-675.

Patitu, C. L., \& Hinton, K. G. (2003). The experiences of African American women faculty and administrators in higher education: Has anything changed?. New Directions for Student Services, 2003(104), 79-93.

Patton-Davis, L., McEwen, M., Rendon, L., \& Howard-Hamilton, M. (2007). Critical race perspectives on theory in student affairs. New Directions for Student Services Vol. 120.

Pierce, J. L. (2012). Racing for Innocence: Whiteness, Gender, and the Backlash Against Affirmative Action. Palo Alto, CA: Stanford University Press.

Preskill, S., \& Brookfield, S. D. (2009). Learning as a way of leading: Lessons from the struggle for social justice. San Francisco, CA: Jossey-Bass.

Reddick, R. J. (2012). Male faculty mentors in black and white. International Journal of Mentoring and Coaching in Education, 1(1), 36-53.

Rhoads, R. A. (1998). Freedom's Web: Student Activism in an Age of Cultural Diversity. Baltimore, MD: Johns Hopkins University Press.

Ropers-Huilman, B., Carwile, L., \& Barnett, K. (2005). Student Activists' Characterizations of Administrators in Higher Education: Perceptions of Power in" the System". The Review of Higher Education, 28(3), 295-312.

Solorzano, D., Ceja, M., \& Yosso, T. (2000). Critical race theory, racial microaggressions, and campus racial climate: The experience of African American college students. The Journal of Negro Education, 69, 60-73.

Squire, D. D. (2016) Engaging race and power in higher education organizations through a critical race institutional logics perspective. Journal of Critical Scholarship on Higher Education and Student Affairs. 2(1), 105-121.

Stockdill, B. C., \& Danico, M. Y. (2012). The ivory tower paradox: Higher education as a site of oppression and resistance. In B. C. Stockdill, \& M. Y. Danico (Eds), Transforming the ivory tower: Challenging racism and homophobia in the academy (pp. 1-30). Honolulu, HI: University of Hawaii Press.

Strayhorn, T. L., \& DeVita, J. M. (2010). African American males' student engagement: A comparison of good practices by institutional type. Journal of African American 
Studies, 14(1), 87-105.

Taylor, C. M., \& Howard-Hamilton, M. F. (1995). Student involvement and racial identity attitudes among African American males. Journal of College Student Development, $36,330-330$.

Tinto, V. (1993). Leaving college: Rethinking the causes and cures of student attrition (2nd Ed.). Chicago: University of Chicago Press.

Turner, C. S. V. (2002). Women of color in academe: Living with multiple marginality. The Journal of Higher Education, 73(1), 74-93.

Weber, M. (2009). The theory of social and economic organization. New York, NY: Simon and Schuster.

Wilder, C. S. (2014). Ebony and ivy: Race, slavery, and the troubled history of America's universities. Bloomsbury Publishing USA.

Yosso, T. J. (2005). Whose culture has capital? A critical race theory discussion of community cultural wealth. Race Ethnicity and Education, 8(1), 69-91. 